\title{
Redefining Immediacy for Email Satisfactory Communication: South-East Nigerian Lecturers' Perspectives
}

\section{Mendefinisikan kembali Kedekatan Berkomunikasi yang Memuaskan melalui Email: Perspektif para Pengajar di Nigeria Tenggara}

\author{
Chinedu Eugenia Anumudu', Megat Al-Imran Yasin', Akmar Ahmad Ghazali', \\ Syed Agil Alsagoff ${ }^{1}$ \\ ${ }^{1}$ Communication Department, Faculty of Modern Languages and Communication, \\ Universiti Putra Malaysia, 43400 UPM Serdang, Selangor Darul Ehsan, Malaysia \\ *Corresponding author, e-mail: munedunwa@gmail.com
}

\begin{abstract}
Notwithstanding the empirical evidence that Nigerian academic staff utilized email as one of asynchronous virtual communications, recent studies pointed that low productivities were still witnessed by them due to email inability of giving them timely responses as viable means of communication. Therefore, this study was necessitated for redefining immediacy effects towards reaching email satisfactory communication among South-East Nigerian academic staff. Qualitative investigative study via case study was conducted towards soliciting their views on how to redefine immediacy for email satisfactory communication. The major findings of the study demonstrated that effective internet availability and affordable subscriptions, homophilous patterns of communications, content structure strategy, enhancing regularly email checking awareness, and power supply availability were the immediate remedies for achieving email satisfactory communication. The study eventually recommended that these factors should be taken into considerations by them towards attaining email satisfactory communication and in other asynchronous virtual communication mediums.
\end{abstract}

Keywords: Redefining Immediacy, Email, Satisfactory Communication, South-East Nigerian Academic Staff.

\begin{abstract}
Abstrak
Terlepas dari bukti empiris bahwa staf akademik Nigeria menggunakan email sebagai salah satu komunikasi virtual asynchronous, studi terbaru menunjukkan bahwa produktivitas rendah masih disaksikan oleh mereka, karena email tidak mampu memberi mereka tanggapan tepat waktu sebagai sarana komunikasi yang layak. Oleh karena itu, penelitian ini diperlukan untuk mendefinisikan kembali efek kedekatan terhadap komunikasi email yang memuaskan antara staf akademik Nigeria Tenggara. Penelitian investigatif kualitatif melalui studi kasus dilakukan untuk meminta pandangan mereka tentang cara mendefinisikan kembali kedekatan untuk komunikasi yang memuaskan melalui email. Temuan utama dari penelitian ini menunjukkan bahwa ketersediaan internet yang efektif dan langganan yang terjangkau, pola komunikasi homofil, strategi struktur konten, meningkatkan kesadaran pengecekan email secara berkala, dan ketersediaan pasokan daya adalah solusi langsung untuk mencapai komunikasi yang memuaskan melalui email. Penelitian ini akhirnya merekomendasikan bahwa faktor-faktor ini harus dipertimbangkan oleh mereka untuk mencapai komunikasi yang memuaskan melalui email dan di media komunikasi virtual asynchronous lainnya.
\end{abstract}

Kata Kunci: Mendefinisikan kembali Kedekatan, Email, Komunikasi yang Memuaskan, Staf Akademik di Nigeria Tenggara. 


\section{Introduction}

The study was conducted among South-East Nigerian academic staff for filling up empirical and knowledge gaps created by previous related studies which only concentrated more on email usage patterns. However, despite the proof that they actually make use of email while discharging their daily clerical tasks, study has shown that use of email has contributed to low productivities in Nigerian higher institutions due to its inability for motivating and hindering prompt feedbacks Mukoroi (2013). Thus, there was necessity for conducting this study towards redefining immediacy effects for email satisfactory communication from these academic staff's views. Besides, their levels of email satisfactory communication were also explored in order to ascertain if it probably contributed to their dissatisfactory communications. Furthermore, previous studies that focused on immediacy concept from other countries were influenced by the studies' settings since what efficiently worked in developed countries might not be effective in emerging societies such as Nigeria.

Consequently, this study was guided by Social Presence Theory (SPT) propounded by Short, Williams, and Christie (1976); because it has immediacy as one of its elements and it has been established as having capability of influencing satisfactory communication on asynchronous virtual media. The theory also revolved on how social clues are transmitted towards enriching satisfactory communication on telecommunication mediums. Thus, immediacy as one of the concepts of this theory originated from Wiener and Mehrabian (1968) and was broadly defined by Baker and Oswald (2010) as physical, communicative and non-communicative behaviours, which help in decreasing both psychological and physical distance among virtual communicating entities towards attaining satisfactory communications. Whereas from the contextual usage in this study, it was referred as communicative and non-communicative behaviours, which would assist in reducing psychological and physical distance among email communicating entities towards attaining satisfactory communications. Nonetheless, Walkem, (2014) perceived immediacy concept from e-learning scenario as getting prompt feedback from communicating individuals at the proper time. However, this scholar emphasized that prompt feedback could only be possible if communicating entities acknowledge that it is their official duty to regularly check their mails and reply them. The scholar added that it could also be facilitated if the messages were clearly written and timely. Similarly, Song, Hollenbeck, and Zinkhan (2015); Kelley and Autman (2014) illustrated that improvement in the immediacy of feedbacks on media was highly necessary for actualizing effective communications. Moreover, the scholars demonstrated that numbers of information cues, personalizing names and rapid feedbacks as antecedents to satisfactory interactions on computer mediated communications.

Whereas, Al Ghamdi, Samarji, and Watt (2016) established that virtual satisfactory communication could be influenced by e-immediacy behaviours such as verbal and nonverbal clues. Furthermore, the scholars presented that immediacy concept could play major roles such as reducing transactional distance between sender and receiver of virtual messages; enhancing relationships and social wellbeing; and expanding social life. Conversely, Sarapin and Morris (2015) postulated that approachability in text-based communication mediums enhanced the possibility of immediacy effects towards reaching gratification and motives behind using a particular media. Nonetheless, the finding was made between professors and students via facebook interactive forum. While Bi, Fussell, and Birnholtz (2014) viewed immediacy concept from embracing traits that are similar with communicating entities on virtual interactions, especially where non-verbal cues 
seemed absent. Nonetheless, the finding was made through behavioural accommodations' theories studies, though it was mediated by cultural background.

Contrarily, among Nigerian academic staff who were the participants of this study, many challenges have been outlined as factors hindering satisfactory use of virtual communication technologies within the institutions' environs. This observation was made regardless that previous studies conducted by Bankole (2013); and Tiwari (2016) firmly attested use of email by academic staff as one of the predominant products of internet. However, much efforts were successively made towards upgrading Information and Communication Technologies (ICT) status in Nigerian public universities in order to compete with the global standard for effective communications and usage (Odediran, Gbadegesin, \& Babalola, 2015). Nonetheless, Odediran et. al (2015) emphasized that the condition of ICT in Nigerian public universities were still dilapidated because of low level of technology usage, inadequate poor financial maintenance and lack of effective policy implementations. These exasperated situations were because, Nigerian government only privatized public universities for the purpose of having authorities over them and not for remedying the poor conditions (Adetunji \& Adetunji, 2015). Similarly, Nigerian Academic Staff Union of Universities (ASUU) equally confirmed the present deteriorations of ICT facilities among Nigerian public universities and blamed its poor state on Nigerian government negligence.

This was because the governments were only said to focus on spending money towards establishing new universities instead of maintaining the existing ones. Additionally, they were said to be more concerned in awarding new projects instead of finishing the already awarded ones and focus on upgrading the existing facilities (ASUU, 2016). Jumare, Tahir, and Hamid (2017) equally added that most of the existing ICT in Nigerian universities were already outdated and needed improvement in order to meet up with international standards. Moreover, the scholars suggested that awareness on the limited ICT should be made so that academic staff and their students would be able to maximize the available ones. Furthermore, Victor and Bolanle (2017) demonstrated that other information and communication technologies such as internets, computer training centers, storing of materials on CD-ROM and projectors were still presently lacked in Nigerian public universities. Thus, it is emphatically known that when there are internet facilities, media content could be easily shared, reproduced and maximized (Sukmono \& Junaedi, 2019). Nevertheless, limited access to computer usage was still serious issues on those campuses. Additionally, Omeluzor, Akibu, and Akinwoye (2016) precisely emphasized on the users of ICT perceptions towards effective maximization of the available resources on the Nigerian campuses. Thus, the scholars further established that challenges such as insufficient awareness, inadequate trainings, unreliable internet connectivity and nonexistence of e-resources in some specific field of studies as issues currently slowing the ample penetrations of ICT in Nigerian public universities.

Therefore, based on these highlighted challenges attested by these scholars as current issues affecting effective use of information and communication technologies within Nigerian public universities, the current study investigated on how immediacy concept would be redefined towards attaining email satisfactory communication with the limited available ICTS. Hence this specific empirical study was still being lacked in the previous studies. Additionally, their level of email satisfactory communication was also explored in this study. Consequently, this study's findings came up with adopting effective internet availability and affordable subscriptions, homophilous patterns of 
communications, content structure strategy, enhancing regularly email checking awareness and power supply availability as remedies that should be considered towards achieving email satisfactory communication among South-East Nigerian academic staff. In line with these, the study's research questions focused on these: what is the level of email satisfactory communication among South-East Nigerian academic staff?; and how would immediacy be redefined towards targeting email satisfactory communication from South-East Nigerian academic staff's perspectives?

\section{Method}

The current study was conducted in South-East Nigerian public universities among 13 participants who were selected through purposive non-probability method because the study focused on specific familiar issue among well-informed individuals as suggested by (Bryman, \& Bell, 2015). Hence, the 13 participants were selected from 6 South-East Nigerian public universities for the interviews as follow:

\begin{tabular}{|c|c|c|}
\hline $\begin{array}{c}\text { Nos of } \\
\text { Participants }\end{array}$ & Position & Institutions of the Participants \\
\hline 3 Participants & $\begin{array}{l}2 \mathrm{PhD} \text { holders and } 1 \text { Master's } \\
\text { degree holder }\end{array}$ & University of Nigeria Nsukka (UNN) \\
\hline 2 Participants & $\begin{array}{c}1 \mathrm{PhD} \text { holder and } 1 \text { Master's } \\
\text { degree holder }\end{array}$ & $\begin{array}{c}\text { Nnamdi Azikiwe University, } \\
\text { Awka (UNIZIK) }\end{array}$ \\
\hline 2 Participants & $\begin{array}{c}1 \text { Associate Professor and } 1 \mathrm{PhD} \\
\text { holder }\end{array}$ & $\begin{array}{c}\text { Chukwuemeka Odumegwu Ojukwu } \\
\text { University (COOU) }\end{array}$ \\
\hline 2 Participants & 1 Professor and $1 \mathrm{PhD}$ holder & Abia State University (ABSU) \\
\hline 2 Participants & $\begin{array}{l}\text { I Associate Professor and } 1 \\
\text { Master's degree holder }\end{array}$ & $\begin{array}{c}\text { Federal University of Technology } \\
\text { Owerri (FUTO) }\end{array}$ \\
\hline 2 Participants & $\begin{array}{l}\text { I Professor and } 1 \text { Master's } \\
\text { degree holder }\end{array}$ & Ebonyi State University (EBSU) \\
\hline Total & 13 & \\
\hline
\end{tabular}

Table 1. Lists of Participants for Interview (source: the researchers)

In terms of research paradigm, qualitative approach was employed in the study because of its suitability for studying a specific phenomenon that needed the participants' viewpoints through investigations for acquiring in-depth data (Qu \& Dumay, 2011). Thus, it was assumed that employing qualitative method would lead to gaining profound understanding on how immediacy concept would be redefined towards achieving email satisfactory communication. Subsequently, instrumental case study form of qualitative design was utilized since the phenomenon explored in the study was a collectively shared experience and this made the method the most suitable for proffering practical solutions to the issue identified in the study (Qu \& Dumay, 2011). However, single case study with multiple constituencies was used in this study for the aim of getting diverse opinions because public universities in Nigeria constituted both state and federal universities. Eventually, interview was used and collected data on how immediacy concept would be redefined towards achieving email satisfactory communication. It was employed because it was deemed appropriate for issues that needed investigations to get the participants' perspectives (Creswell, 2009). Thereafter, semi-structured interview form was engaged because of its ability of exploring issues that were not initially included in the research guided questions.

The unit of analysis employed while analyzing the data of this study was thematic analysis. It was employed in analyzing the interview responses from the participants. The reasons behind thematic analysis is for extracting themes from the transcribed data, 
arranging the themes and arriving at richer descriptions of them (Harding, 2018). Inferring from Gibbs (2018) thematic analysis is not just counting of words and phrases within a transcribed data but identifying both implicit and explicit concepts from the transcribed data. Furthermore, Lune, and Berg (2016) pinpointed this method as one of the most interesting procedures because it makes provisions for discovery of concepts and themes from the transcribed data. The thematic analysis employed in this study comprised six-step outline. The six stages were getting familiarized with the data, allotting of preliminary codes in data, probing for themes in codes through the interviews' outcomes, reviewing of themes, definition and naming themes; and finally, report writing. Furthermore, the data analyzed in the study was a primary one gathered from the researcher's interviews. At the end of the interview, the research transcribed all the interviewee' responses, got familiarized with the data, coded and categorized similar ideas from them. By so doing, it helped the researcher to absorb and improve the data towards developing themes (Rubin, Herbert \& Rubin, 2011). Consequently, no segment was neglected from the data while highlighting the vital codes that would probably be instrumental in subsequent stages of the analyses. Thereafter, the themes derived at earlier stage were revised for the purpose of integrating similar subthemes. The provisional categories designed from the data were also deductively tested for searching for more proof towards supporting the last series of categories. Eventually, five themes were derived from the analyses and were given names. These themes were discussed in the next paragraph.

\section{Results and Discussion}

The source of the findings presented in this discussion section was directly from the researcher's data analysis collected during the interviews phase. Therefore, it did not involve any secondary data. Subsequently, the findings towards understanding how immediacy concept would be redefined for achieving email satisfactory communication and the level of the satisfaction from the participants' views would be discussed one after the other. In terms of the first research question, which focused on knowing the level of email satisfactory communication was described it to be low and moderate.

From the result, most of the interviewees described it low, while few stated it to be moderate. According to the participants who described it low, they pointed reasons behind it to be lecturers' inability to check email for couple of days, time impediment, attitudinal issue, not having access to smartphones and internet, fluctuating internet service, poor internet connectivity in various faculties; non-internet coverage in most places in Nigeria and unstable power supply. Inferring from one of the participants, this excerpt was given: "You want me to be honest? If you want me to be honest, I am grossly disappointed with the system and I will rate it low. Aaah ... I don't know, I don't know, I will be messing my university up. However, we don't even have effective system and constant power supply that would bring about high email satisfactory communication in most of the universities."

According to this participant, emphasis was placed on non-availability of institutional internet services and intermittent power supply. So, it implied that these reasons given by this participant and issues pointed by other interviewees as already listed were obstacles towards reaching high email satisfactory communication. Therefore, the level of email satisfactory communication would be improved if these pointed factors are made available. Hence, it is recommended that university managements should intervene 
and proffer solutions on how to deal with the issues mentioned by them if they actually want to increase productivities from the academic staff in terms of tasks that required to be accomplished via email or other virtual communication forums. Few of these factor such as poor internet connectivity and intermittent power supply were in line with what previous studies earlier pointed as causes of ICT usage deterioration in Nigerian universities (Anasi, Ukangwa, \& Fagbe, 2018).

Furthermore, one of the participants who rated email satisfactory communication moderate, stated this: "It is moderate, very moderate, aaah... is not..., well, it is still evolving. It is a technology that came in here not up to 5 years. So, it is still evolving. So, I will say it is moderate for now. It is evolving technology. They are just trying to make us use the institutional email but is evolving. Yes, though there is internet interruption, it is more or less a kind of, is more or less personal, it is more of personal thing."

Accordingly, it implied that using email among academic staff in institutional setting for achieving certain motives was still a new development, though the participant equally highlighted internet interruptions as one of the obstacles towards achieving satisfactory communication. Others added reasons such as having not yet perceived the need for using email in institutional environments, lack of support for internet facility and inadequate proficiency in using communication technologies However, the above excerpt suggested that personal attitudes were also affecting it. Therefore, this called for awareness towards changing their attitudes and start using email to discharge some clerical duties. The interviews' outcomes to some extent supported the findings of Omeluzor, Akibu, and Akinwoye (2016) that lack of awareness towards ICT usage was one of the challenges facing Nigerian academic staff, although the findings was made from Nigerian public universities located in other regions of Nigeria. Thus, there is need to adequately sensitize academic staff on the usefulness of exploring the few available communication technologies while discharging their duties.

Descriptions of Themes that Emerged from the Researchers' Interviews Analysis on How Immediacy Concept would be Redefined for Email Satisfactory Communication

Five themes emerged from the analysis. The themes were: (1) effective internet availability and affordable subscriptions; (2) homophilous patterns of communications; (3) content structure strategy; (4) enhancing regularly email checking awareness; (5) power supply availability. Each of the themes would be described one after the other.

Effective Internet Availability and Affordable Subscriptions

The above theme was the first theme that emerged from the interview. Most of the participants emphasized on the need to provide better bandwidth and infrastructures in order to avoid flimsy excuses attributed to non-availability and internet interruptions as reasons for not accessing emails. Moreover, it was suggested that institutions should be able to adopt independent source of internet services. The participants also suggested the need to subside internet subscription prices, so that an average person would be able to afford it.

Thus, one of the participants stated this: "Well, if the internet service is ok, and the cost is reasonable, I believe it will promote prompt feedback. The internet is not ok in this country, not just in this university. It is terrible because even Nigerian government has not got any internet services. They rely on South Africa, that is, that their Multinational Telecommunication Network (MTN) things and others. So, they have not been able to establish something that will really help the country. Most of internet services suppliers to Nigeria are all foreign. It constituted serious problems for Nigerians because the cost is exorbitant. The people find it very very difficult to meet the financial requirement. You 
buy Nigerian airtime of \#500 or \#1,000, within few seconds, it is gone. So, they feel reluctant to keep using it. Another thing is that this idea of buying airtime is terrible, if they will be able to introduce this Router system they use in the United Kingdom, it will help to enhance internet services provided you maintained the monthly subscription."

From the above excerpt and other participants' responses, it proposed that Nigeria should be able to establish self-internet providers and reduce over reliance on foreign internet bodies from other countries like South Africa. This was because the participants pointed that far distance also contributed in worsening the availability of effective and reliable internet services. Additionally, plea for reducing the monthly internet subscription prices were also highlighted. The interviewee further suggested that Nigeria should adopt Router system that will enable them to pay monthly according to services provided to them. Therefore, these findings recommended that immediacy for email satisfactory communication would be achieved by academic staff if there are effective independent internet body suppliers. Thus, called for Nigerian government to intervene towards establishing viable country owned effective internet suppliers and reduce over dependence on foreign ones. Additionally, it was commended that internet subscriptions should be reduced and provision for speedy internet be made, so that average Nigerian academic staff would be able to afford personal subscriptions for enabling them to have steady access to their emails and improve its satisfactory communication.

Another participant further stated this: "It is just part of what I was saying the last time, if the institution will provide internet whether we later personally subscribe to internet or not, it doesn't matter but in an institution like this, that should have better knowledge of... you know? Oooh... what these communication facilities will do in aiding communication, so the effectiveness of such facilities in aiding communication should be of paramount interest to the authorities of the institution. So, if these facilities are there, the prime essence of communication and advancement in it for personal reasons and official reasons will improve but once you don't have these things, there is a limit to what you can do. You know? The response is still low."

Thus, according to this interviewee's excerpt, it highlighted that various institutions should be able to provide and maintain its own internet facilities. By so doing, the quintessence for using email for both personal and official issues would be improved towards achieving email satisfactory communication. Therefore, it recommended that immediacy for email satisfactory communication among South-East Nigerian academic staff in public universities would be obtained if various universities are able to establish and maintain their own independent source of internet services. Hence, it is commended that each university should adopt and maintain its own internet supply in order to encourage satisfactory use of email.

Homophilous Patterns of Communications

This was the second theme that emerged from interview's analysis. Regarding this theme, the interviewees generally emphasized that discussing convergent mutual issues, showing mutual rapport with colleagues and having sufficient volume of interactions via email will improve email satisfactory communication. They further suggested that having colleagues who equally give concern to email prompt responses, and perceiving email as better forum for dispatching official issues will induce immediacy towards reaching email satisfactory communication. Additionally, they recommended that observing principle of cooperation, having mutual values for co-workers, responsiveness and commitment of colleagues were equally the parts of immediacy effects towards 
achieving email satisfactory communication. They also specified that having related patterns of communication with colleagues and prior knowledge about the behaviours of communicating partners would definitely enhance immediacy concept for email satisfactory communication. Thus, all their emphases focused on observing homophilous patterns of communications among their colleagues. In other words, incorporating similar ways of communications would definitely enhance immediacy effect towards achieving email satisfactory communication.

Thus, this was one of the excerpts for supporting the theme: "Yes, definitely, when there is similar patterns of communication, it becomes easier and more effective. When your single of experience agrees with the single experience of the other person, it becomes more effective, definitely, yes. If the person I am communicating with or I am exchanging my ideas, if the person is at the same level with me, the discussion of the message or everything becomes more effective, because he can communicate well at the same time. But when you are communicating with those who are below you or those who are higher than you, there is what we called empathy. If you are communicating with those below you, you introduce empathy. You must bring yourself to their level to be able to understand and appreciate them better. So, if you are equally dealing with people who are above you, you will be struggling to live up to their expectations. So, that is why I am saying that there is what we call in communication heterophilous and homophilous, they are very serious in communication. And again, there is what is called the feed forward in communication. So, who are you communicating with? The prior knowledge, what you know about the person you are communicating with, may affect the communication."

The above response equally suggested that observing principle of cooperation, exhibiting similar communication patterns while engaging in interactions, showing empathy and having mutual values for co-workers would redefine immediacy effects for attaining email satisfactory communication. Therefore, the participants' views recommended that their colleagues should embrace related ways of communication if an immediacy effect for email satisfactory communication is actually aimed among them. It was also partly in congruent with Zinaida and Havivi (2019) study's input, which suggested that socializing on digital media equally required employing effective communication strategies that would seem similarly attractive to communicating entities for achieving the desirable outcomes.

Content Structure Strategy

This was the third theme that surfaced from the study. Since email is an asynchronous mediated written communication where physical presence of both communicating entities are not required, it is expected that the way the contents are structured should be given paramount attention. Therefore, the participants suggested that emails within institutions should be personalized with the receiver's names before sending it to the receiver irrespective of knowing whom the receivers are. They equally added that politeness of language used for conveying email contents, appropriate choice of words and engaging semi-formal languages while interacting with co-workers via email should be considered. Furthermore, they pointed that incorporating cordial tone, conciseness of email content and its clarity as another good approaches that will help to appreciate the content of the email towards enhancing immediacy for email satisfactory communication. Additionally, they pointed that the briefness of the content, structuring of email content in way that will solicit view point and adding profile of previous successes of interaction via email as other approaches that will help to redefine immediacy effect for email satisfactory communication.

Jurnal The Messenger, Vol. 12, No. 1, January 2020, pp. 84-96 
Subsequently, this was one of the excerpts for backing- up the third theme: "Aaah... well, I have two views on that, the first one though a mail may be to everybody, a general mail, but if it is possible to attach the person's name, address it to the person in his name, not minding that the thing is getting into his email address but attaching his name, that is one. The other one is the language, people who are going to be dealing with people officially through email should be given orientation on the type of language they will be using to address to the people, so that it wouldn't be offensive and it will not be also too playful. It has to be something that will get the message across."

The above interviewee and other participants' views highlighted on the need of personalizing mails by attaching the names of the receivers on it to make it look more personal and also the senders should be mindful of the languages employed while constructing mails in order to attract immediacy effect for email satisfactory communication. Therefore, the content structures should be much valued if email satisfactory communication are targeted.

Another interviewee emphatically highlighted on the briefness of the content of email, thus responded this: "One, it depends on the lengthiness of the what you are to go through, because you know, for example now, if I'm at work, if something is long, I may not have time to start going through. But if it is just having few words, which you can just go through and give the person feedback, it will help to enhance immediacy result towards achieving email satisfactory. The first thing that can put someone off, is if it is lengthen."

This participant categorically pointed that lengthiness of mails' contents can easily discourage prompt feedback towards immediacy outcome and puts the receiver of such email off, especially if the receiver is so busy with other clerical duties. Hence it should be minimized for the purpose of encouraging immediacy responses for email satisfactory communication. This equally recommended that focus should be given to email content structure strategy in order to propel its satisfactory communication.

Another interviewee also stressed on choice of words that should be employed while constructing email in order not to make it look offensive but polite in structure. Thus responded this: "Like in official communication here, we use hello to make it as if we are calling or we are discussing. We don't get too formal, because while working with your fellow staff, it is a semi-formal relationship. The way you will issue oral instruction is not like in the military, it is not like command. Can you please help do this, assist do this. So, such language could be used. You can say, personally, I use their first names and not their official designation, say hello Charles, kindly do this, this... this is very urgent. Is like some lives are built into the written mail to make it effective, the choice of words and politeness of them are very important."

The above response highlighted not just on the languages but also on choice of words which should appear polite and not as commanding tones while communicating with coworkers via email. Therefore, the study's outcomes commended that email content structure strategies should be considered if they intend to reach immediacy effect for email satisfactory communication.

Enhancing Regularly Email Checking Awareness

This was the fourth theme derived from the interviews' data analysis. The interviewees generally suggested that enlightening of academic staff on the importance of regularly checking emails, and sending of reminder when delay in reply is experienced should also help in improving immediacy effect for achieving email satisfactory 
communication. They equally suggested that there should be platform in the email setting where "urgent" should be attached to any sent emails. By so doing, it will go a long way in prioritizing the urgency of the message sent via email for the aim of instigating immediacy outcome towards email satisfactory communication.

Thus, this was one of the interviewees' except for augmenting the fourth theme: "I think enlightenment might make it happen, then may be, if you are sending email, they should have a platform to show the emergency, sorry, you tag it as urgent. There should be enlightenment; you should tag it as urgent, so that the person that is getting it will know that. Such platform should be added in this our new evolving technology. I don't think it is for now, it is not there now. And then they could add this calendar something, so that most times, if you are sending an email outside and you want a response, you should also attach a calendar to it that this is a deadline for this something. So, that, like in outlook, there is platform for calendar, do you understand? So the person may say between 2 to 3 o'clock, It will now be known that this is the expiration of that thing, so with such thing, you might hopefully get prompt feedback."

Therefore, this specific excerpt and other participants' views as earlier stated, emphasized on enlightening them on the usefulness of giving prompt feedback to any received mails. Additionally, the outcome suggested that provision of platforms where urgency and calendar regarding deadline dates for responses should be integrated in the evolving communication technologies such as email towards improving its immediacy effect for the satisfactory communication. Consequently, all their suggestions focused on enhancing regularly email checking awareness. Hence, it was unanimously recommended that South-East Nigerian academic staff should incorporate it if they aim to achieve immediacy result towards email satisfactory communication.

Power Supply Availability

This was the last theme that emerged from the interviews' data analysis. According to the participants, non-availability of power supply and intermittent power supply were pointed as hindrances towards enhancing immediacy responses for email satisfactory communication. Consequently, interviewees bitterly complained about piles of work left undone due to absence of power supply. In other words, the participants pointed it was really affecting their productivities' rates. Furthermore, it was stated that having steady low batteries most times prevented them from frequently checking their emails via smartphones and other communication technologies for providing prompt feedbacks.

Thus, this was one of the excerpts for supporting the above theme: "Remember what I told you when my friend came in here, I said what are we even talking, we are lucky we even have power supply now, by the time, may be between now and 12pm or Ipm, it will be off. You find out that, aaah... We don't even have the service, in most of universities; you ought to have your devices, your system before you, so that you can access your mail, you can do most of the things but they are not here. All what people use here are their personal and you find out that people are discouraged, they don't stay long due to interrupted power supply."

The above reply categorically pointed that even when there is power supply on campuses, it is rationed and comes only when it is the university' premises turn to have it. Additionally, due to not having enabling environment where these facilities are available to use at any moment, it discouraged academic staff from staying long in their offices, except those that have alternative to power supply like generators. In other words, it was pointed as one of the factors contributing to email dissatisfactory communication and also hinders the effectiveness of using other electronic communication devices that

Jurnal The Messenger, Vol. 12, No. 1, January 2020, pp. 84-96 
need power supply before they could be used. Therefore, the study's interview outcome commended that steady power supply or alternative universities' independent source of power supple should be installed in order to encourage immediacy effect for email satisfactory communication.

\section{Conclusion}

The major findings of this study recommended that homophilous patterns of communications; content structure strategy and enhancing regularly email checking awareness should be cultivated and embraced by South-East Nigerian academic staff if they anticipate to achieve immediacy effects for email satisfactory communication and in other asynchronous virtual communication mediums. It was further recommended that effective internet availability and affordable subscriptions cum power supply availability should be considered and implemented by Nigerian government. Thus, by providing such basic amenities in Nigerian public universities, it would definitely go a long way in enhancing immediacy effects towards achieving email satisfactory communication and other communication technologies that also needed such amenities for effective usage. Moreover, it is commended that other emerging countries should also adopt these factors towards embracing satisfactory communication in asynchronous virtual communications environments since the outcomes similarly emerged from a developing country.

Furthermore, the outcomes of this study have some implications such as assisting in expanding social presence theory by integrating these newly outlined factors in it as well as broadening its theoretical framework for further studies. It has also provided some proposed factors for conceptual framework and hypotheses testing for subsequent scholars, specifically via quantitative research studies. Therefore, quantitative studies are subsequently needed towards evaluating correlations between the identified factors and satisfactory communications in other computer mediated communication mediums. Thus, by engaging in such studies, research paradigm would be more broadened.

\section{Acknowledgements}

The author would like to appreciate all the scholarly contributions made by individual supervisory committee members towards making the study a successful one. Further appreciation goes to the participants for the willingness in granting their opinions during the interviews period.

\section{References}

Adetunji, A. T., \& Adetunji, A. V. (2015). Deregulation Policy: Impact on Nigerian Universities. International Journal in Management and Social Science, 3(8), 313321.

Al Ghamdi, A., Samarji, A., \& Watt, A. (2016). Essential considerations in distance education in KSA: Teacher immediacy in a virtual teaching and learning environment. International Journal of Information and Education Technology, 6(1), 17.

Anasi, S. N., Ukangwa, C. C., \& Fagbe, A. (2018). University libraries-bridging digital gaps and accelerating the achievement of sustainable development goals through information and communication technologies. World Journal of Science, Technology and Sustainable Development, 15(1), 13-25.

ASUU (2016). Facts and figures: real reasons behind ASUU strike (November 20, 2016) 
http://www.naijaperminute.com.ng/2016/11/20/facts-figures-real-reasonsbehindasuu-strike. (n.d.).

Baker, L. R., \& Oswald, D. L. (2010). Shyness and online social networking services. Journal of Social and Personal Relationships, 27(7), 873-889.

Bankole, O. M. (2013). The use of internet services and resources by scientists at Olabisi Onabanjo University, Ago Iwoye, Nigeria. Program, 47(1), 15-33.

Bi, N., Fussell, S. R., \& Birnholtz, J. (2014). To be like you to be liked by you: cultural effects on adjusting awareness information gathering behavior. In Proceedings of the 5th ACM international conference on Collaboration across boundaries: culture, distance \& technology (pp. 31-40). ACM.

Bryman, A., \& Bell, E. (2015). Business research methods. Oxford University Press, USA.

Creswell, J. W. (2009). Research design: Qualitative, quantitative, and mixed methods approaches (Vol. 4). Sage Thousand Oaks, CA.

Gibbs, G. R. (2018). Analyzing qualitative data (Vol. 6). Sage.

Harding, J. (2018). Qualitative data analysis: From start to finish. SAGE Publications Limited.

Jumare, M. A., Tahir, S. M., \& Hamid, A. T. (2017). The use of ICT in Nigerian universities: A study of Kaduna State University, Kaduna. International Journal of Advanced Research in IT and Engineering, 6(7), 1-12.

Kelley, S., \& Autman, H. (2014). Effective Computer-Mediated Business Communication: Fostering Immediacy. The Journal of Research in Business Education, 56(2), 48.

Lune, H., \& Berg, B. L. (2016). Qualitative research methods for the social sciences. Pearson Higher Ed.

Mukoroi, A. S. (2013). Improving industrial harmony and staff performance in a school organization through effective communication. International Journal of Scientific Research in Education, 6(3), 263-270.

Odediran, S. J., Gbadegesin, J. T., \& Babalola, M. O. (2015). Facilities management practices in the Nigerian public universities. Journal of Facilities Management, $13(1), 5-26$.

Omeluzor, S. U., Akibu, A. A., \& Akinwoye, O. A. (2016). Students' perception, use and challenges of electronic information resources in Federal University of petroleum resources Effurun Library in Nigeria. Library Philosophy and Practice (E-Journal), 1428.

Qu, S. Q., \& Dumay, J. (2011). The qualitative research interview. Qualitative Research in Accounting \& Management, 8(3), 238-264.

Rubin, H. J., \& Rubin, I. S. (2011). Qualitative interviewing: The art of hearing data. Sage.

Sarapin, S. H., \& Morris, P. L. (2015). Faculty and Facebook friending: instructor-student online social communication from the professor's perspective. The Internet and Higher Education, 27, 14-23.

Short, J., Williams, E., \& Christie, B. (1976). The social psychology of telecommunications. John Wiley\& Sons.

Song, J. H., Hollenbeck, C. R., \& Zinkhan, G. M. (2015). Managing Interactive Communications with Customers: The Effects of Social Presence Cues, Personalization, the Speed of Feedback and Situation. In Proceedings of the 2007 Academy of Marketing Science (AMS) Annual Conference (pp. 296-299). Springer.

Jurnal The Messenger, Vol. 12, No. 1, January 2020, pp. 84-96 
Sukmono, F. G., \& Junaedi, F. (2019). Citizen Journalism and Online Community Media: A Case Study of pwmu. co. Jurnal The Messenger, 11(2), 198-208.

Tiwari, S. K. (2016). A Study on Impact of ICT on Library and Information Services. International Journal of Recent Advances in Engineering \& Technology, 4(1), 2631.

Victor, A. A., \& Bolanle, R. R. (2017). Extent of Information and Communication Technology (ICT) Utilization for Students' Learning in Tertiary Institutions in Ondo State, Nigeria. Online Submission, 3(3), 2369-2376.

Walkem, K. (2014). Instructional immediacy in elearning. Collegian, 21(3), 179-184.

Wiener, M., \& Mehrabian, A. (1968). Language within language: Immediacy, a channel in verbal communication. Ardent Media.

Zinaida, R. S., \& Havivi, S. L. (2019). Understanding the Communication Strategy of Women's Rights Protection in the Digital Era through Website. Jurnal The Messenger, 11(2), 244-256. 